\title{
Adaptability and interspecific variability in growth and leaf traits of eucalypt
}

\author{
Chrissy Garel Makouanzi \\ Ekomono ${ }^{(1-2-3)}$, \\ Castela Bath Shéba Vitel \\ Loubassou $^{(3)}$, \\ Mavie Parfait Mbama ${ }^{(4)}$, \\ Grace Jopaul Loubota Panzou ${ }^{(5)}$, \\ Philippe Vigneron ${ }^{(6)}$
}

\begin{abstract}
Effective adaptability of plants to new environments can be analysed in terms of survival rate. Analysing the traits that favour adaptation to environmental changes provides a more in-depth understanding of the mechanisms involved. Local adaptation occurs because different environmental factors exert selective pressure across habitats. Understanding the leaf mechanisms underlying plant survival and growth is crucial to determine why local adaptation involves trade-offs. A comparative provenance test on 29 eucalyptus species was conducted to improve our understanding of species adaptation strategies on coastal plains of Pointe-Noire, Republic of the Congo. We studied the different functional traits to determine how plants function and to highlight the different species' adaptive strategies. For each species, survival, growth traits and leaf traits were measured, and the climatic factors of the origin area for each species was taken into account. Cluster analysis was performed on groups of species with a similar growth strategy. The results revealed general trends that explain the physiological mechanisms involved in the species' local adaptation. Indeed, species have survived to current environmental changes by adjusting their specific leaf area plasticity. The 32 provenances of eucalyptus were subdivided into four groups by cluster analysis. The first cluster included two species ( $E$. pilularis and $E$. peltata) that are totally unsuited to the local conditions in Pointe-Noire, with the slowest growth rate and smallest specific leaf area. The second cluster contained species that showed a wide variety of growing strategies, allowing them to adapt to local conditions. The third cluster included a species that is specialised in obtaining large quantities of resources, while investing very little in growth. The fourth cluster included species that acquired and used resources at a slow rate. Leaf anatomy was quite responsive to climatic conditions. We evaluated the different strategies and found that eucalyptus species had very diverse functional traits, which may explain their broad ecological range.
\end{abstract}

Keywords: Adaptability, Eucalyptus, Foliar Traits, Growth Strategies, Clustering Analysis

\section{Introduction}

The predictions suggest that Africa will be severely impacted by climate change. There is a significant risk that many forest ecosystems will not have the adaptive capacity to supply vital goods and services (FAO 2015). To face global climate changes, species must adapt to new environments (Jump \& Peñuelas 2005, Franks \& Hoffmann 2012). Thus, although this is a daunting task, understanding the capacity of species to adapt is increasingly important for conservation and biodiversity management (Loo et al. 2011, Dillon et al. 2014). Such task entails the study of morphological, physiological and phenological characteristics involved in the ecological strategies adopted in response to environmental factors (Pérez-Harguindeguy et al. 2013).

The study of functional traits, especially in plants, has a long tradition in ecological research (Vandewalle et al. 2010). Leaf traits may reflect adaptation mechanisms of plants to the environment; in particular, leaf morphological traits like specific leaf area, leaf thickness and leaf density may better reflect the changes in environmental factors (Ahrens et al. 2020) such as temperature, light intensity and water status. Conversely, environmental changes can led to unprecedented changes in ecosystems including plant growth strategies.

The trade-offs between functional traits depends on how plants acquire, use and conserve the resources (Reich et al. 2003). The plasticity in functional traits is responsible for much of the phenotypic variation observed in non-native populations, and allows introduced species to grow successfully in new conditions, despite the limited genetic variation (Drenovsky et al. 2012). Genetic diversity within and among stands is the linchpin for current and future forest development, and is crucial for the survival and adaptation of species (Kremer 2000).

The current production context which involves unsustainable land use changes, as well as future climate change scenarios, call for more detailed studies on local varietal adaptation in order to reduce the use of land and optimize future timber production. In this context, the eucalyptus im- 
provement programme in the Congo should move towards the selection of plastic genotypes with a more efficient use of resources.

Adapting to different environmental conditions entails costly fitness trade-offs (VanWallendael et al. 2019). Assisted migration involving individuals or populations of a species is potentially an important strategy to respond to climate change, though this approach is not widely used (FAO 2014). In general, several Eucalyptus species show remarkable plasticity, which allows adaptation to hostile environments, especially nutrient-poor soils (Cossalter et al. 1999) and hot arid areas (Saadaoui et al. 2018). Although certain species are known to better perform on poor soils (Laclau et al. 2016), few studies focused on the physiological basis of this ecological feature.

In the Congo, the first attempts to introduce eucalyptus date back to 1953. Subsequently, several species and provenance trials have been conducted. Several studies on their productivity revealed that only

Tab. 1 - List of studied species and their subgenera.

\begin{tabular}{|c|c|c|c|}
\hline $\begin{array}{l}\text { Species } \\
\text { code }\end{array}$ & Subgenus & Species & Provenance \\
\hline 1 & Alveolata & E. microcorys & Beerburrum (Australia) \\
\hline 2 & Blakella & E. tesselaris & Mareeba (Australia) \\
\hline 3 & \multirow[t]{6}{*}{ Corymbia } & E. citriodora & Ord Irvinbanck (Australia) \\
\hline 4 & & E. maculata & Rockhampton (Australia) \\
\hline 5 & & E. nesophila & Jimmy’s Creek, Coboutg Peninsula (Australia) \\
\hline 6 & & E. peltata & Mantuan (Australia) \\
\hline 7 & & E. polycarpa & Est Gue Goyder river (Australia) \\
\hline 8 & & E. torelliana & Flaggy Creek, QLD (Australia) \\
\hline 9 & \multirow[t]{4}{*}{ Eucalyptus } & E. acmenoides & Wild Cattle (Australia) \\
\hline 10 & & E. phaeotricha & Noosa Heads (Australia) \\
\hline 11 & & E. pilularis & Moleton (Australia) \\
\hline 12 & & E. umbra & Elliot river (Australia) \\
\hline 13 & Eudesmia & E. tetrodonta & SE Maningrida (Australia) \\
\hline 14 & Idiogenes & E. cloeziana & Gympie (Australia) \\
\hline 15 & Minutifructus & E. raveretiana & Exe Creek, Ouest Mckay (Australia) \\
\hline 16 & \multirow{17}{*}{$\begin{array}{l}\text { Symphyo- } \\
\text { myrtus }\end{array}$} & E. alba & Sud Cooktown (Australia) \\
\hline 17 & & E. alba & Natar Bora (Timor) \\
\hline 18 & & E. apodophylla & Ouest Pentecost river, Gibb River (Australia) \\
\hline 19 & & E. bigalerita & S-O Katherine Kununurra river (Australia) \\
\hline 20 & & E. brassiana & Cape York peninsula, Coen (Australia) \\
\hline 21 & & E. exserta & Mckay Rockhampton (Australia) \\
\hline 22 & & E. grandis & Est Atherton, QLD (Australia) \\
\hline 23 & & E. paniculata & Nord Raymond Terrasse (Australia) \\
\hline 24 & & E. pellita & Pinnacle (Australia) \\
\hline 25 & & E. propinqua & Clouds Creek SF Grafton (Australia) \\
\hline 26 & & E. punctata & Barakula SFNW Chinchilla (Australia) \\
\hline 27 & & E. resinifera & 10km Ravenshoe (Australia) \\
\hline 28 & & E. robusta & Noosa (Australia) \\
\hline 29 & & E. tereticornis & Helenvale (Australia) \\
\hline 30 & & E. urophylla & Mte Lewotobi (Indonesia) \\
\hline 31 & & E. urophylla & Flores Arbau Ulu (Indonesia) \\
\hline 32 & & E. urophylla & Arafalaca, Ouest Alor (Timor) \\
\hline
\end{tabular}

annual rainfall is approximately $1200 \mathrm{~mm}$; daily temperature is $25-26{ }^{\circ} \mathrm{C}$ in the rainy season (October to May) and $22-23{ }^{\circ} \mathrm{C}$ in the dry season (June to September). The average monthly rainfall during the rainy season ranges from 83 to $92 \mathrm{~mm}$, and during the dry season from 1 to $20 \mathrm{~mm}$ (Jamet \& Rieffel 1976). Relative humidity is high (85\%) with low seasonal variability ( $2 \%)$. The soil is ferralitic and highly desaturated in bases (Nzila 2001).

We conducted the present study in a Eucalyptus provenance trial which included 32 provenances belonging to 29 species (Tab. 1). The seeds used for seedling production were collected from different parts of Australia (North, North East, East and South East coasts) and Indonesia (Fig. 1).

\section{Tree measurements}

The experimental design consisted of 4 blocks of 128 plots ( 32 per block); each plot contains 9 trees representing a single provenance. The plots were randomly distributed into the blocks. Originally, each plot was planted with spacing of $4.70 \times 2.65 \mathrm{~m}$ (about 800 trees ha $^{-1}$ ). Trees were measured at two dates: after 15 months (1.2 years) since their establishment (in February during the short dry season) and after 54 months (4.5 years, in April during the main rainy season).

We first evaluated the survival rate (SR, \%) of the trees at each age at the plot level, and the difference in survival between 54 and 15 months (eqn. 1):

$$
S R=\frac{n_{\text {live }}}{n_{\text {tot }}} \cdot 100
$$

where $n_{\text {live }}$ is the number of live trees at the plot level and $n_{\text {tot }}$ is the total number of tree established in the plot. On each tree, we performed non-destructive quantitative measurements including collar circumference, total height and leaf measurements. Collar circumference (CC, cm) was measured with a tape around the trunk base. Total tree height $(H T, m)$ was measured with a Vertex ${ }^{\circledR}$ IV (Haglöf, Långsele, Sweden) hypsometer at a distance approximately equivalent to tree height. Leaf variables, including specific leaf area (SLA), leaf thickness ( $L T, \mathrm{~mm})$ and leaf density ( $L D, \mathrm{~kg}$ $\mathrm{m}^{-3}$ ) were measured for 10 leaves per tree harvested from the upper and lower crown. The 10 adult leaves were chosen with a fully expanded blade (juvenile and senescent leaves were excluded) and free of damage. Leaf thickness was measured immediately after leaf removal with a digital micrometer (Mitutoyo, Kawasaki, Japan) at a point mid-way along the length of the leaf and mid-way between the median and leaf edge. Leaf area was measured in the laboratory using scans and the software MatLab ${ }^{\circledR}$ (MathWorks Corp., Natick, MA, USA) for image processing.

Leaves were then dried at $65{ }^{\circ} \mathrm{C}$ to constant weight. The dry weight was used in conjunction with the area measurements to calculate specific leaf area (SLA, $\mathrm{m}^{2} \mathrm{~kg}^{-1}$ ) 
Fig. 1 - Location of seed harvesting sites for the studied eucalypt species/provenances.

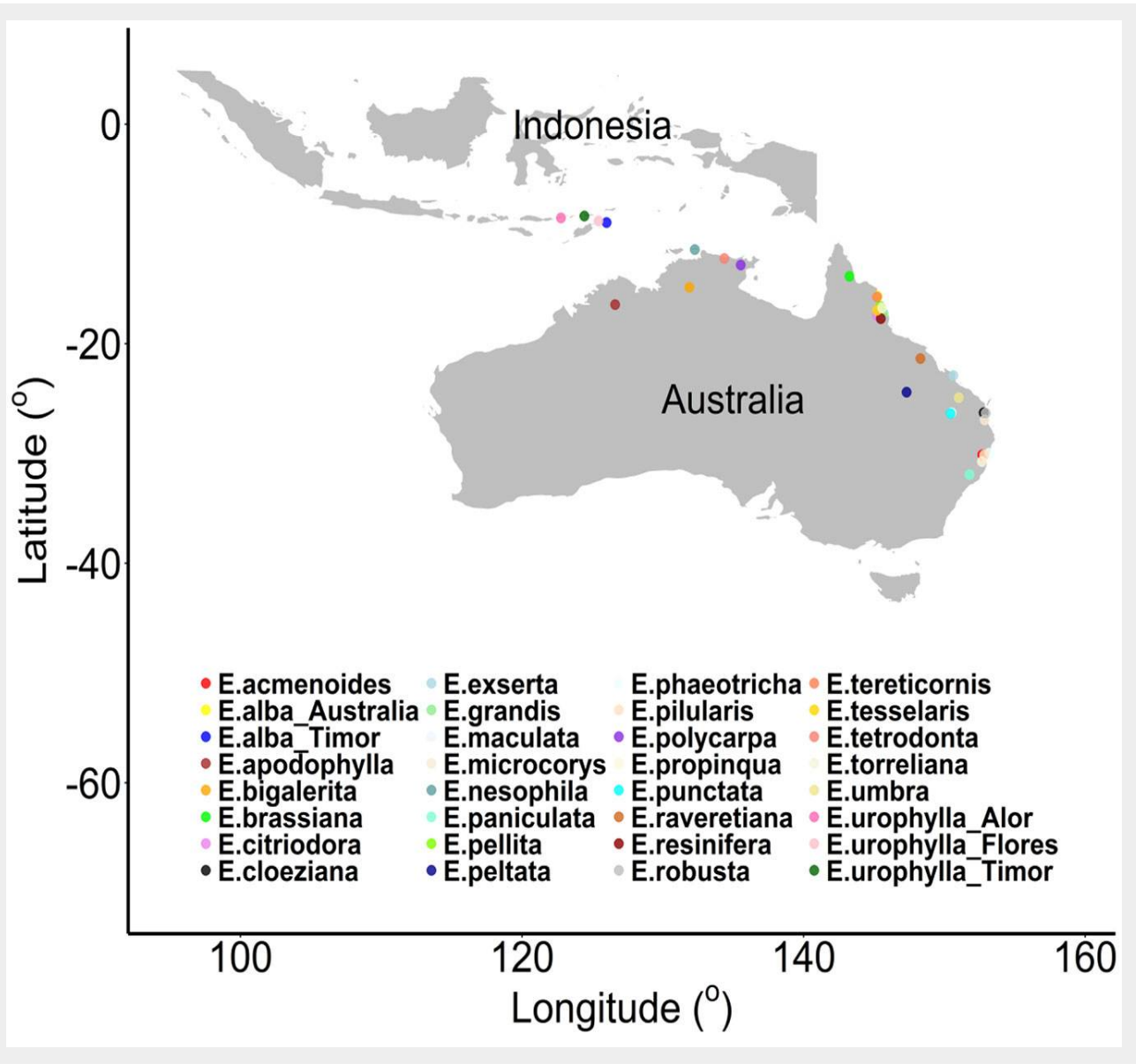

using the following formula (eqn. 2):

$$
S L A=\frac{L A}{L M}
$$

where $L A$ and $L M$ are respectively the area and the dry mass of 10 sampled leaves. The leaf density ( $L D, \mathrm{~kg} \mathrm{~m}^{-3}$ ) was calculated using SLA and LT (Sefton et al. 2002) as follows (eqn. 3 ):

$$
L D=\frac{1}{S L A \cdot L T}
$$

\section{Climate data}

We used data from the meteorological stations (http://www.bom.gov.au/) at each site where we collected the seeds of eucalyptus species in Australia and Indonesia. The following 18 climatic variables were considered (Tab. S1 in Supplementary material): 1- average annual rainfall (AAR); 2maximum annual rainfall (MAR); 3- minimum annual rainfall (mAR); 4- maximum monthly average rainfall (MMAR); 5- minimum monthly average rainfall (mMAR); 6number of months of rainfall less than 50 $\mathrm{mm}$ (NR50); 7- average annual temperature (AAT); 8- maximum monthly temperature (MMT); 9- minimum average temperature (mMT); 10- maximum monthly average temperature (MMAT); 11- minimum monthly average temperature (mMAT); 12- number of days below $40^{\circ} \mathrm{C}$ (ND40); 13- number of freezing days (NFD); 14- annual potential evapotranspiration (PE); 15- annual solar radiation (SR); 16- altitude (A); 17- longitude
(Long); 18- latitude (Lat). Data on the same 18 climatic variables were also collected at the planting site (Pointe-Noire).

\section{Statistical analysis}

The following linear mixed model was used to perform ANOVA for survival rate (at the plot level), functional traits and growth (at tree level - eqn. 4):

$$
y=\mu+X_{b} b+Z_{s b} s b+Z_{s p} s p+\varepsilon
$$

where $y$ is the vector of the response variable; $\mu$ is the overall mean; $X$ and $Z$ are the design matrix connecting the fixed and random effects to the data, respectively; $b$ is a vector of fixed effects due to the blocks; $s b \sim \mathrm{N}\left(0, \sigma_{\text {sbld }}^{2}\right)$ is a vector of the random subgenus effect; $\sigma_{s b}^{2}$ is the variance related to the subgenus effect; Id is the identity matrix; $s p \sim N\left(0, \sigma_{\text {spld }}^{2}\right)$ is a vector of the random species effect; $\sigma_{\text {sp }}^{2}$ is the variance related to the species effect; $\varepsilon$ $\sim \mathrm{N}\left(0, \sigma_{\varepsilon \mathrm{ld}}^{2}\right)$ is a vector of the residual effect. Before performing ANOVA on survival rate, we calculated an angular arc sinus transformation (eqn. 5)

$$
p^{\prime}=\arcsin \sqrt{p}
$$

where $p^{\prime}$ is the transformed value of survival rate and $p$ is the original value of survival rate for each plot.

To detect covariations among functional traits, we used pairwise Pearson's multiple correlation tests to analyse bivariate and multivariate relationships. To analyse the multivariate relationships, a principal component analysis (PCA) was performed in order to identify the similarities between the climatic characteristics of the area of origin of the species and the area where the species were introduced. At provenances level, functional traits were estimated from the tree measurements at 15 and 54 months (Tab. S2 in Supplementary material). The $k$-means partitioning method was performed to assign observations to clusters relating to growth and functional traits at the age of 54 months.

All statistical analyses were performed using the open-source software R v. 4.0.3.

\section{Results}

\section{Variation of functional traits between} species

\section{Survival rate}

The survival rate was significantly different between subgenera at $15(P=0.0003)$ and 54 months $(P<0.001)$. Likewise, a similar effect was observed among species at 15 months $(P<0.001)$ and at 54 months $(P<0.001)$. At both ages, the subgenera Blakella and Idiogenes had the highest survival rates of $91 \%$ and $87 \%$, respectively, whereas the subgenera Eucalyptus and Eudesmia had the lowest survival rates of $35 \%$ and $13 \%$, respectively (Fig. 2). The species $E$. tetrodonta (17\%), E. peltata (12\%) and E. pilularis (0\%) had the lowest survival rates at 54 


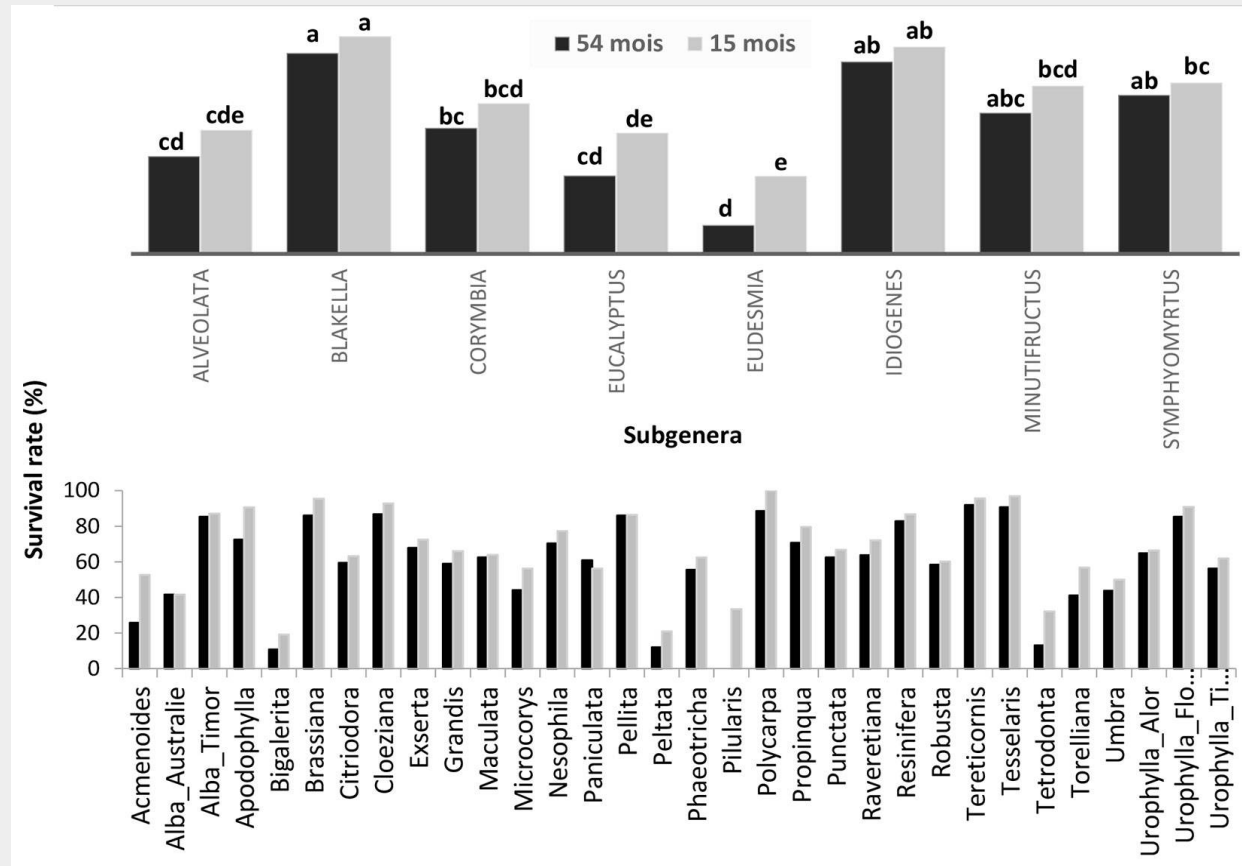

Fig. 2 - Mean values of survival rate by subgenera and species/provenances. Different letters above the bars indicate significant differences $(p<0.05)$ between group means after Tukey's test.

Species/Provenances



Fig. 3 - Difference in survival rate (\%) of eucalyptus species/provenances between 54 and 15 months after tree establishment. months, while E. tereticornis (96\%) and E. tesselaris (97\%) had the highest survival rates at the same age (Fig. 2). The survival rate of E. robusta and E. alba_Australia remained the same between 15 and 54 months. That of species like E. tereticornis, E. alba Timor, E. urophylla, E. maculata, E. citriodora, E. exserta, E. resinifera and $E$. pellita did not change considerably, while for E. pilularis, E. acmenoides, E. peltata, E. tetrodonta, E. torelliana and E. apodophylla, the change of survival rate over time is very marked (Fig. 3 ).

\section{Growth and leaf traits}

Growth traits increased according to ages from 15 months to 54 months. The ANOVA results showed significant differences between species of the same subgenus and between subgenera for all traits (Tab. 2). Leaf thickness (LT) remained almost stable, while specific leaf area (SLA) increased and leaf density ( $L D$ ) decreased from 15 to 54 months. The subgenera Symphyomyrtus, Idiogenes, Eucalyptus and Corymbia showed greater variations in $L T$, whereas their SLA values remained low. In contrast, the subgenera Minutifructus, Eudesmia, Blakella and Alveolata had high SLA and low $L T$ values. The Flores provenance of $E$. urophylla showed one of the best growth rates and a high SLA value.

\section{Correlations between traits}

The juvenile-adult correlations (Fig. 4) indicated close ranking at different ages for $L T$ and height. In contrast, the $L D$ ranking changed completely from 15 to 54 months. There was a strong and positive correlation between height and collar circumference at 15 months (Pearson's $r=0.79$ ) and 54 months (Pearson's $r=0.84$ ), and a moderate and positive correlation between 
growth and survival (Pearson's $r=0.41$ to 0.57). Between 15 and 54 months, the correlation of individual SLA values was moderate (Pearson's $r=0.49$ ). Further, there was a weak correlation between growth and SLA (Pearson's $r=0.10$ to 0.28). We found a negative correlation between SLA and $L D$ (Pearson's $r=-0.59$ to -0.50 ), as well as between SLA and LT (Pearson's $r=-0.67$ to -0.42), and also between $L D$ and $L T$ (Pearson's $r=-0.50$ to -0.17 ) from 15 to 54 months.

\section{PCA and clustering analysis}

The PCA results indicated that the main components (two first axes) account for $66 \%$ of the total variation (Fig. 5). The two main components were associated with temperature and solar radiation (41.16\%) and rainfall $(24.84 \%)$, respectively. The results showed that species like E. tereticornis (from Halenvale), E. nesophilla (Coboutg peninsula), E. tetrodonta (South Est Maningrida), E. polycarpa (Est Gue Goyder river), E. brassiana (Cape York peninsula) and E. alba (Timor) were found in areas where the climatic conditions are similar to the Congolese coastal savannas (Fig. 5). On the contrary, E. punctata, E. maculata, E. acmenoides and $E$. resinifera were originated from areas whose climatic conditions differed from the area of introduction.

The results of the cluster analysis suggest
Tab. 2 - Descriptive statistics and Anova results of variables studied at 15 and 54 months. (SR): survival rate (\%); (HT): tree height (m); (SLA): specific leaf area $\left(\mathrm{m}^{2} \mathrm{~kg}^{-1}\right)$; (LT): leaf thickness (mm); (LD): leaf density ( $\left.\mathrm{kg} \mathrm{m}^{-3}\right)$; (SD): standard deviation; (Max): maximum; (Min): minimum. 15 and 54 indicate the age tree (in months).

\begin{tabular}{|c|c|c|c|c|c|c|c|c|}
\hline \multirow[b]{2}{*}{ Traits } & \multirow[b]{2}{*}{ Unit } & \multirow[b]{2}{*}{ Mean } & \multirow[b]{2}{*}{ SD } & \multirow[b]{2}{*}{ Max } & \multirow[b]{2}{*}{ Min } & \multicolumn{3}{|c|}{$(\mathrm{Pr}>\mathrm{F})$} \\
\hline & & & & & & Block & $\begin{array}{l}\text { Sub- } \\
\text { genus }\end{array}$ & $\begin{array}{l}\text { Species/ } \\
\text { Provenance }\end{array}$ \\
\hline SR15 & $\%$ & 68.93 & 21.07 & 100.00 & 17.85 & 0.273 & 0.0003 & $<0.0001$ \\
\hline SR54 & $\%$ & 61.24 & 23.40 & 91.83 & 0.00 & 0.177 & $<0.0001$ & $<0.0001$ \\
\hline HT15 & $\mathrm{m}$ & 2.02 & 0.87 & 5.55 & 0.55 & 0.195 & 0.023 & 0.003 \\
\hline HT54 & $\mathrm{m}$ & 7.99 & 3.26 & 18.60 & 1.50 & $<0.0001$ & $<0.0001$ & $<0.0001$ \\
\hline CC15 & $\mathrm{cm}$ & 7.27 & 3.87 & 26.12 & 0.94 & 0.188 & 0.068 & 0.003 \\
\hline CC54 & $\mathrm{cm}$ & 29.98 & 12.84 & 72.80 & 1.50 & $<0.0001$ & $<0.0001$ & $<0.0001$ \\
\hline SLA15 & $\mathrm{m}^{2} \mathrm{~kg}^{-1}$ & 80.43 & 16.79 & 148.84 & 45.76 & 0.392 & $<0.0001$ & $<0.0001$ \\
\hline SLA54 & $\mathrm{m}^{2} \mathrm{~kg}^{-1}$ & 259.73 & 102.00 & 529.46 & 38.36 & $<0.0001$ & $<0.0001$ & $<0.0001$ \\
\hline LT15 & $\mathrm{mm}$ & 0.28 & 0.05 & 0.46 & 0.14 & 0.0002 & $<0.0001$ & $<0.0001$ \\
\hline LT54 & $\mathrm{mm}$ & 0.27 & 0.05 & 0.42 & 0.16 & $<0.0001$ & $<0.0001$ & $<0.0001$ \\
\hline LD15 & $\mathrm{kg} \mathrm{m}^{-3}$ & 0.46 & 0.06 & 0.60 & 0.32 & $<0.0001$ & $<0.0001$ & $<0.0001$ \\
\hline LD54 & $\mathrm{kg} \mathrm{m}^{-3}$ & 0.18 & 0.11 & 1.15 & 0.08 & $<0.0001$ & $<0.0001$ & $<0.0001$ \\
\hline
\end{tabular}

that the 32 provenances analyzed can be present. The second cluster contained subdivided into four groups (Fig. 6). The species with a wide variety of responses in first cluster included E. pilularis and E. terms of their growth strategy. Some peltata, with the lowest growth rate and species had a very high growth rate and a the smallest SLA. At the end of the trial, no large SLA, for example, E. cloeziana, E. uroindividuals representing E. pilularis were phylla_Flores and E. alba_Timor. This clus-



Fig. 4 - Correlations between juvenile and adult traits. (HT): total tree height (m); (CC): collar circumference (cm); (LT): leaf thickness (mm); (SLA): specific leaf area $\left(\mathrm{m}^{2} \mathrm{~kg}^{-1}\right)$; (LD): leaf density $\left(\mathrm{kg} \mathrm{m}^{-3}\right) ; 15$ and 54 indicate the age of tree (in months). 


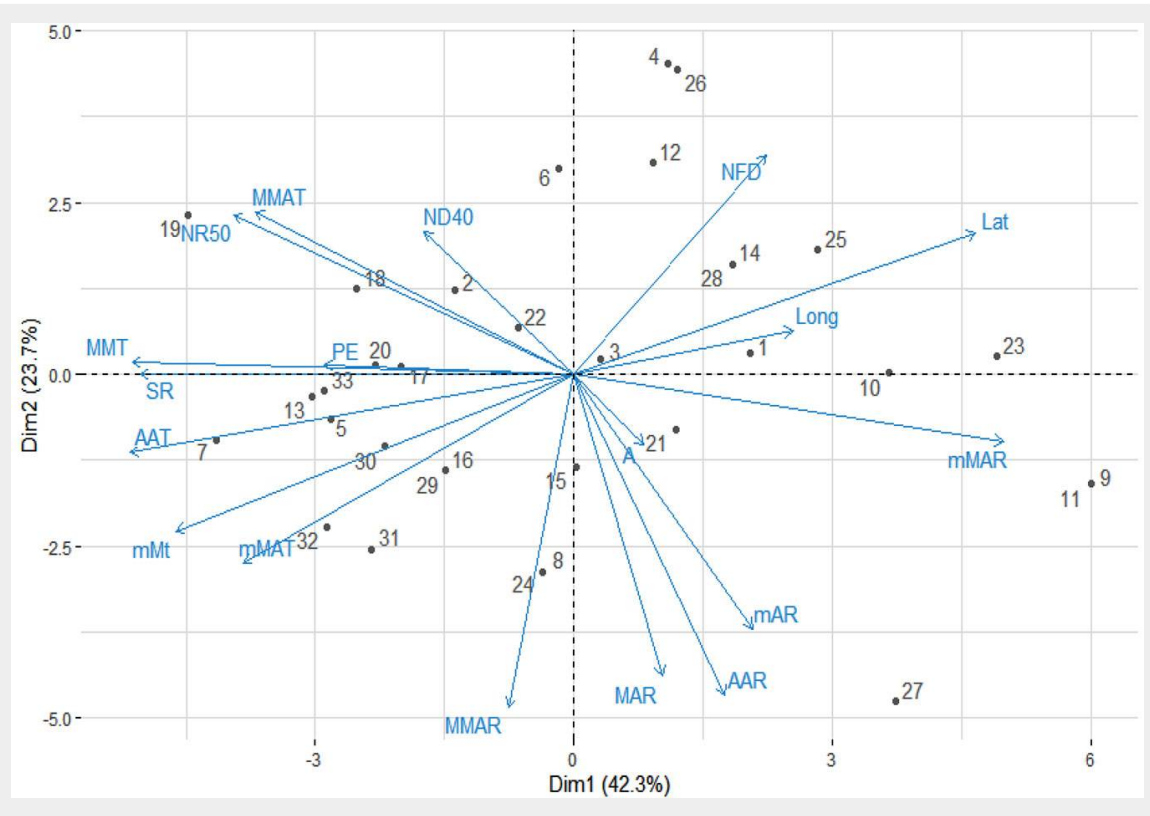

Fig. 5 - Principal component analysis biplot. Numbers refer to the different eucalypt species/provenances. (1): E. microcorys; (2): E. tesselaris; (3): E. citriodora; (4): E. maculata; (5): E. nesophila; (6): E. peltata; (7): E. polycarpa; (8): E. torelliana; (9): E .acmenoides; (10): E. phaeotricha; (11): E. pilularis; (12): E. umbra; (13): E. tetrodonta; (14): E. cloeziana; (15): E. raveretiana; (16): E. alba_Australia; (17): E. alba_Timor; (18): E. apodophylla; (19): E.bigalerita; (20): E. brassiana; (21): E. exserta; (22): $\bar{E}$. grandis; (23): E. paniculata; (24): E. pellita; (25): E. propinqua; (26): E. punctata; (27): E. resinifera; (28): E. robusta; (29): E. tereticornis; (30): E. urophylla Mte Lewotobi; (31): E. urophylla_Flores; (32): E. urophylla_Timor; (33): Pointe-noire (planting site).

ter also included species with medium nances 14, 31, 22, 24, 30, 4, 3 (Fig. 6) having growth rates and low SLA, like E. robusta a good growth and survival, as well as and $E$. brassiana, and species with slower medium-high SLA; and (ii) C2b including growth and higher SLA, like E. toreliana. Al- provenances 21, 8, 20, 7, 27, 29, 23, 28, 10, together, cluster 2 can be divided into two 32, 5, 5, 17 (Fig. 6) with various characterisothers clusters: (i) C2a including prove- tics. The species in cluster 3 had large SLA

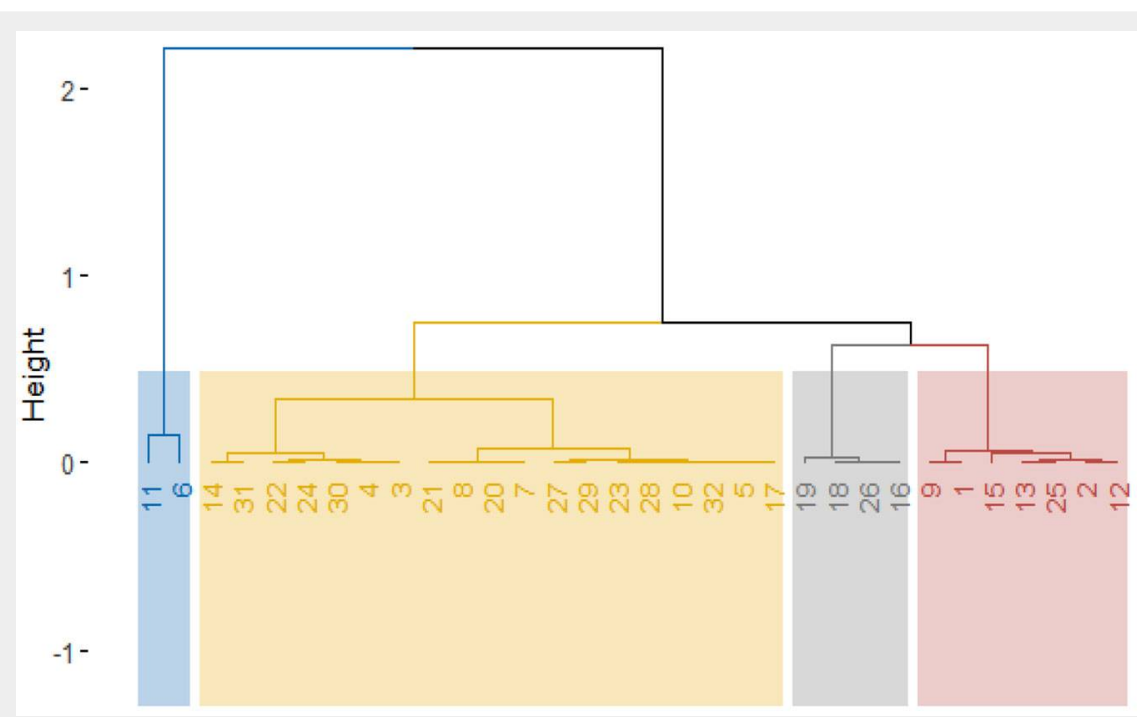

Fig. 6 - Cluster dendrogram of species/provenances. Cluster 1: (11) E. pilularis and (6) E. peltata; Cluster 2: (14) E. cloeziana, (31) E. urophylla_Flores, (22) E. grandis, (24) E. pellita, (30) E. urophylla_Mte Lewotobi, (4) E. maculata, (3) E. citriodora, (21) E. exserta, (8) E. torelliana, (20) $\bar{E}$. brassiana, (7) E. polycarpa, (27) E. resinifera, (29) E. tereticornis, (23) E. paniculata, (28) E. robusta, (10) E. phaeotricha, (32) E. urophylla_Timor and (5) E. nesophila, (17) E. alba_Timor; Cluster 3: (19) E. bigalerita, (18) E. apodophylla, (26) E. punctata and (16) E. alb $\bar{a}$ _Australia; Cluster 4: (9) E. acmenoides, (1) E. microcorys, (15) E. raveretiana, (13) E. tetrodonta, (25) E. propinqua, (2) E. tesselaris and (12) E. umbra. values but slow growth. The last cluster includes the species with slow growth and small SLA, like E. tesselaris.

\section{Discussion}

\section{Variability of functional traits among species}

Survival is the first fundamental criterion to assess adaptation (Gardner 2017). Plants compete for light, water, nutrients, air and space to survive. In our study, ranking species according to their survival rate changed significantly from 15 months to 54 months. The $100 \%$ mortality of E. pilularis trees after 54 months from establishment reflects their very poor adaptation to the local conditions in Pointe-Noire. This result corroborated those obtained by Brezard (1982) in the same region. It is worth noting that the climate of the original area for E. pilularis is very different from that at the plantation site. However, this result needs to be confirmed as only 9 plants of this species were initially included in the experiment (Tab. S2 in Supplementary material).

Species with a low survival rate but good growth, like E. citriodora, were not necessarily poorly adapted in the study area, as several factors may be involved, such as plantation density leading to competition between species. Indeed, intense competition between adjacent plots could have led to differences between fast- and slowgrowing species, with the suppression of the latter species (Hunde et al. 2007).

Our study revealed a difference of survival rate and growth both among species of the same subgenus and among subgenera. One of the characteristics in which species of the same or different habitats vary is their growth potential. In a common environment, trade-offs between functional traits are the basis for the observation of different growth strategies and finally different strategies of adaptation (Reich et al. 2003). Adaptations can be divided into two general categories: functional adaptations, which help an organism to survive in its environment; and growth and reproductive adaptations, which help an organism to grow and reproduce successfully. Both are required to ensure the "full adaptation".

\section{Correlation}

All growth traits were positively correlated between 15 and 54 months since tree establishment. The stability of leaf thickness and the decrease in leaf density led to an increase in SLA between 15 and 54 months. This result can be explained by the fact that water was a limiting factor at 15 months, while at 54 months this was less limiting because of the root development over a larger area and greater depth (Thongo M'Bou 2008).

Our results showed negative and significant correlations between SLA, LT and LD. These results corroborated those of Vile et al. (2005) and Niinemets (1999). Low val- 
ues for SLA due to thicker and/or denser leaves contribute to leaf life span, nutrient retention and protection against desiccation (Ackerly et al. 2002). From the correlations between height and functional traits, we were able to identify the different species' strategies to acquire and use the available environmental resources.

\section{Species' adaptive strategies}

Functional traits play a critical role in the adaptation process (Bouvet et al. 2020). Understanding local adaptive species traits according to climatic factors is key when it comes to developing plantation strategies (Wright et al. 2018). It was firstly assumed that species from areas with climatic conditions similar to those occurring in PointeNoire would be better suited than those from areas with a different climate. This hypothesis was only verified for one species, E. tereticornis, which achieved a good balance between resource acquisition and use. However, some species from areas with very different climatic characteristics compared to those at Pointe-Noire appear to be more suitable, as in the case of most species in cluster 2 . These species thrive in humid, subhumid, tropical or subtropical regions with rainfall of 1100 to $1500 \mathrm{~mm}$ and a dry season lasting 1 to 5 months. A similar rainfall pattern is found in the Congo. The eucalypts' adaptations allow many species to thrive under often difficult conditions, with poor soils and highly variable rainfall. Consequently, a small number of eucalypt species are grown very successfully in plantations (Saadaoui et al. 2018). Genetic diversity is valuable for species survival and adaptation. Some individuals carry genes that allow them to respond to environmental constraints and enhance their adaptive capacity more successfully than others (Savolainen et al. 2013). Genetic variations can, therefore, modulate the local effects of environmental change (Parmesan 2006). Local adaptation can be constrained by natural selection and gene flow (Kawecki \& Ebert 2004, Leimu \& Fischer 2008). Previous studies revealed that local adaptation among different populations (and provenances) of $E$. camaldulensis could be due to variation in adaptive phenotypes, which correspond to the local environment. These include morphological traits (growth form, leaf thickness, stomatal density and phenology James \& Bell 1995), growth rate (Otegbeye 1985), wood properties (El-Lakany et al. 1980), physiological responses (Morshet 1981), and drought tolerance (Lemcoff et al. 2002). The adaptive clines inferred from phenotypic variation were supported by evidence of genetic adaptation in coding genes (Thumma et al. 2012).

Leaf traits do not vary randomly, but depend on trade-offs from investing carbon in leaves (Wright et al. 2004). Specific leaf area is an important functional trait because it is an indicator of relative growth rate, stress tolerance and leaf life span. It is generally assumed that intraspecific SLA variation is largely due to environmentally induced phenotypic plasticity (Liu et al. 2017). However, genetic effects should also be considered such as local adaptation or genetic drift (Scheepens et al. 2010). At the interspecific level, functional traits can explain community composition and structure (Lavorel \& Garnier 2002, Díaz et al. 2004). They can also be used to classify plant species' strategies according to Grime (1977) or to explain species occurrence and distribution (Díaz et al. 1998). Our results suggest that population of different eucalypt species could be able to survive under different climate conditions by adjusting their SLA. In the long term, phenotypic plasticity may allow populations to adapt genetically to environmental changes via genetic assimilation (Price et al. 2003).

The results of cluster analysis showed that the first group includes two species which are totally unsuited to the local conditions in Pointe-Noire. Conversely, species of the second cluster can adapt to the local conditions in Pointe-Noire because of their greater plasticity. Some species can rapidly exploit the environmental resources and allocate them to development, while others show a slow resource acquisition but a fairly efficient use. We found that species in the third cluster had strategies allowing them to acquire resources rapidly with a slow return in terms of investment on leaf economic spectrum (Wright et al. 2004). According to Lambers \& Poorter (1992), these species are specialised in acquiring large quantities of resources (water, light, carbon), while investing very little in growth. Finally, the fourth cluster includes species whose strategy involves a slow acquisition and use of resources, thus resulting in their poor growth due to the reduced photosynthetic capacity.

\section{Conclusion}

Our study provides important advances for the understanding the adaptive strategies of Eucalyptus spp. in the experimental conditions at Pointe-Noire, Republic of the Congo. Based on leaf traits and growth, four major groups of species were identified: (i) species with a large SLA and good growth; (ii) species with a small SLA and poor growth; (iii) efficient species with small SLA and very good growth; and (iv) species with large SLA and poor growth. The species included in the groups (ii) and (iv) are the least suitable to the environmental conditions at the trial site; those in the group (iv) maximise the capture of resources, but have poor growth.

Following this study, it would be relevant to determine the differential expression of genes involved in growth in different provenances and contrasting environments. Further study should focus on species' different strategies for acquiring and using resources in their area of origin and the area of introduction. A combined phenotypic and genomic approach (Steane et al. 2017) should be included in future studies of plant adaptation to local conditions in the Republic of the Congo.

\section{Acknowledgements}

We are grateful to Pacifique Ntadi and the CRDPI technical team for field harvesting. We would like to thank the Conservation Action Research Network (CARN) of the Congo Basin Forest Partnership (CBFP) for their help to support this study.

$\mathrm{PhV}$ and CGME conceived and designed the experiments; CBSVL and MPM performed the trials; CGME and GJLP carried out data analysis. CGME took the lead in writing the manuscript and all authors provided critical feedback.

\section{References}

Ackerly D, Knight C, Weiss S, Barton K, Starmer K (2002). Leaf size, specific leaf area and microhabitat distribution of chaparral woody plants: contrasting patterns in species level and community level analyses. Oecologia 130 (3): 449457. - doi: $10.1007 /$ s004420100805

Ahrens CW, Andrew ME, Mazanec RA, Ruthrof KX, Challis A, Hardy G, Byrne M, Tissue DT, Rymer PD (2020). Plant functional traits differ in adaptability and are predicted to be differentially affected by climate change. Ecology and Evolution 10: 232-248. - doi: 10.1002/ece3.5890 Bouvet J-M, Makouanzi Ekomono CG, Brendel O, Laclau J-P, Bouillet J-P, Epron D (2020). Selecting for water use efficiency, wood chemical traits and biomass with genomics selection in a Eucalyptus breeding program. Forest Ecology and Management 465: 118092. - doi: 10.1016/j. foreco.2020.118092

Brezard JM (1982). Les eucalyptus introduits au Congo 1953-1981 [Eucalyptus introduced to Congo 1953-1981]. Note interne CTFT, PointeNoire, Republic of Congo, pp. 100.

Cossalter C, Vigneron P, Brooker MIH (1999). Eucalyptus d'Australie. Habitats naturels et dynamique d'évolution [Australian eucalyptus. Natural habitats and dynamics of evolution]. Le Flamboyant 49: 15-20. [in French] [online] URL: http://www.cifor.org/knowledge/publication/56 5/

Díaz S, Cabido M, Casanoves F (1998). Plant functional traits and environmental filters at a regional scale. Journal of Vegetation Science 9: 113-122. - doi: $10.2307 / 3237229$

Díaz S, Hodgson JG, Thompson K, Cabido M, Cornelissen JHC, Jalili A, Montserrat-Martí G, Grime JP, Zarrinkamar F, Asri Y, Band SR, Basconcelo S, Castro-Díez P, Funes G, Hamzehee B, Khoshnevi $M$, Pérez-Harguindeguy $N$, Pérez-Rontomé MC, Shirvany FA, Vendramini F, Yazdani S, Abbas-Azimi R, Bogaard A, Boustani S, Charles M, Dehghan M, De Torres-Espuny L, Falczuk V, Guerrero-Campo J, Hynd A, Jones G, Kowsary E, Kazemi-Saeed F, Maestro-Martínez M, RomoDíez A, Shaw S, Siavash B, Villar-Salvador P, Zak MR (2004). The plant traits that drive ecosystems: evidence from three continents. Journal of Vegetation Science 15: 295-304. - doi: 10.1111/j. 1654-1103.2004.tbo2266.x

Dillon S, McEvoy R, Baldwin DS, Rees GN, Parsons Y, Southerton S (2014). Characterisation 
of adaptive genetic diversity in environmentally contrasted populations of Eucalyptus camaldulensis Dehn. (River Red Gum). PLoS One 9 (8): e103515. - doi: 10.1371/journal.pone.0103515 Drenovsky RE, Grewell BJ, D'Antonio CM, Funk JL, James JJ, Molinari N, Parker IM, Richards CL (2012). A functional trait perspective on plant invasion. Annals of Botany 110 (1): 141-153. - doi: 10.1093/aob/mcs100

El-Lakany MH, El-Osta ML, Badran AO (1980). Evaluation of newly introduced Eucalyptus camaldulensis provenances in Egypt. Alexandria Journal of Agricultural Research 28: 309-319.

FAO (2014). Global plan of action for the conservation, sustainable use and development of forest genetic resources. Food and Agriculture Organization of the United Nations, Rome, Italy, pp. 31. [online] URL: http://www.fao.org/ 3/a-i3849e.pdf

FAO (2015). Coping with climate change - the roles of genetics resources for food and agriculture. Food and Agriculture Organization of the United Nations, Rome, Italy, pp. 130.

Franks SJ, Hoffmann AA (2012). Genetics of climate change adaptation. Annual Review of Genetics 46: 185-208. - doi: 10.1146/annurev-genet110711-155511

Gardner A (2017). The purpose of adaptation. Interface Focus 7: 20170005. - doi: 10.1098/rsfs. 2017.0005

Grime JP (1977). Evidence for the existence of three primary strategies in plants and its relevance to ecological and evolutionary theory. The American Naturalist 111: 1169-1195. - doi: 10.1086/283244

Groulez J (1964). Introduction d'eucalyptus au Congo Brazzaville [Introduction of eucalyptus to Congo Brazzaville]. Bois et Forêts des Tropiques 93: 3-14. [in French] [online] URL: http:// revues.cirad.fr/index.php/BFT/article/view/1893 4/18693

Hunde T, Belachew Gizachew B, Harwood C (2007). Genetic variation in survival and growth of Eucalyptus globulus ssp. globulus in Ethiopia. Australian Forestry 70 (1): 48-52. - doi: 10.1080/ 00049158.2007 .10676262

James S, Bell D (1995). Morphology and anatomy of leaves of Eucalyptus camaldulensis clones: variation between geographically separated locations. Australian Journal of Botany 43: 415-433. - doi: 10.1071/BT9950415

Jamet R, Rieffel JM (1976). Carte pédologique du Congo à $1 / 200.000$, feuille Pointe-Noire, feuille Loubomo, notice d'exploitation $n^{\circ} 65$ [Soil map of Congo at 1/200.000, Pointe-Noire sheet, Loubomo sheet, operating manual no. 65]. ORSTOM, Paris, France, pp. 177. [in French] [online] URL: http://www.documentation.ird.fr/ hor/fdi:08621

Jump AS, Peñuelas J (2005). Running to stand still: adaptation and the response of plants to rapid climate change. Ecology Letters 8: 10101020. - doi: 10.1111/j.1461-0248.2005.00796.x

Kawecki TJ, Ebert D (2004). Conceptual issues in local adaptation. Ecology Letters 7: 1225-1241. doi: 10.1111/j.1461-0248.2004.00684.x

Kremer A (2000). Changements climatiques et diversité génétique [Climate change and genetic diversity]. Revue Forestière Française 52: 9198. [in French] - doi: 10.4267/2042/5408

Laclau J-P, Gay F, Bouillet J-P, Bouvet J-M, Chaix
G, Clément-Demange A, Do F, Epron D, Favreau $B$, Gion J-M, Nouvellon Y, Pujade-Renaud V, Thaler P, Verhaegen D, Vigneron P (2016). Adaptation and mitigation in tropical tree plantations. In: "Climate Change and Agriculture Worldwide" (Torquebiau E ed). Springer, Dordrecht, Netherlands, pp. 197-208. - doi: 10.1007/ 978-94-017-7462-8_15

Lambers H, Poorter H (1992). Inherent variation in growth rate between higher plants: a search for physiological causes and ecological consequences. Advances in Ecological Research 23: 187-261. - doi: 10.1016/S0065-2504(08)60148-8 Lavorel S, Garnier E (2002). Predicting changes in community composition and ecosystem functioning from plant traits: revisiting the Holy Grail. Functional Ecology 16: 545-556. - doi: 10.1046/j.1365-2435.2002.00664.x

Leimu R, Fischer M (2008). A meta-analysis of local adaptation in plants. PLoS One 3 (12): e4010. doi: 10.1371/journal.pone.0004010

Lemcoff JH, Guarnaschelli AB, Garau AM, Prystupa P (2002). Elastic and osmotic adjustments in rooted cuttings of several clones of Eucalyptus camaldulensis Dehn. from southeastern Australia after a drought. Flora - Morphology, Distribution. Functional Ecology of Plants 197: 134142. - doi: 10.1078/0367-2530-00023

Liu M, Wang Z, Li S, Lu X, Wang X, Han X (2017). Changes in specific leaf area of dominant plants in temperate grasslands along a $2500-\mathrm{km}$ transect in northern China. Scientific Reports 7 : 10780. - doi: 10.1038/s41598-017-11133-z

Loo J, Fady B, Dawson I, Vinceti B, Baldinelli G (2011). Climate change and forest genetic resources: state of knowledge, risks and opportunities. Commission on Genetic Resources for Food and Agriculture, FAO Background Study Paper No. 56, Food and Agriculture Organization of the United Nations, Rome, Italy, pp. 29. [online] URL: http://hal.inrae.fr/hal-02808387

Morshet S (1981). Physiological activity in a semiarid environment of Eucalyptus camaldulensis Dehn. from two provenances. Australian Journal of Botany 29: 97-110. - doi: 10.1071/BT981 0097

Niinemets U (1999). Research review. Components of leaf dry mass per area-thickness and density-alter leaf photosynthetic capacity in reverse directions in woody plants. New Phytologist 144 (1): 35-47. - doi: 10.1046/j.1469-8137.19 99.00466.x

Nzila JDD (2001). Caractérisation minéralogique des sols ferralitiques sableux sous plantation d'Eucalyptus et sous savane naturelle de la région de Pointe-Noire (Congo). [Mineralogical characterization of sandy ferralitic soils under Eucalyptus plantation and natural savannah in the Pointe-Noire region (Congo)]. Rapport UR2PI, Pointe-Noire, Republic of Congo, pp. 51. [in French]

Otegbeye GO (1985). Provenance productivity in Eucalyptus camaldulensis and its implications to genetic improvement in the savanna region of Nigeria. Silvae Genetica 121-126.

Parmesan C (2006). Ecological and evolutionary responses to recent climate change. Annual Review of Ecology, Evolution, and Systematics 37: 637-669. - doi: 10.1146/annurev.ecolsys.37.0913 05.110100

Pérez-Harguindeguy N, Díaz S, Garnier E, Lavorel
S, Poorter H, Jaureguiberry P, Bret-Harte MS, Cornwell WK, Craine JM, Gurvich DE, Urcelay C, Veneklaas EJ, Reich PB, Poorter L, Wright IJ, Ray P, Enrico L, Pausas JG, de Vos AC, Buchmann N, Funes $G$, Quétier F, Hodgson JG, Thompson K, Morgan HD, ter Steege H, Sack L, Blonder B, Poschlod P, Vaieretti MV, Conti G, Staver AC, Aquino S, Cornelissen JH (2013). New handbook for standardised measurement of plant functional traits worldwide. Australian Journal of Botany 61 (3): 167. - doi: 10.1071/BT12 225

Price TD, Qvarnström A, Irwin DE (2003). The role of phenotypic plasticity in driving genetic evolution. Proceedings of the Royal Society of London, Series B 270: 1433-1440. - doi: 10.1098/ rspb.2003.2372

Reich PB, Wright IJ, Cavender-Bares J, Craine JM, Oleksyn J, Westoby M, Walters MB (2003). The evolution of plant functional variation: traits, spectra, and strategies. International Journal of Plant Sciences 164 (S3): S143-S164. - doi: 10.108 $6 / 374368$

Saadaoui E, Ben Yahia K, Dhahri S, Mohamed Lahbib Ben Jamaa ML, Mohamed Larbi Khouja $M L$ (2018). An overview of adaptative responses to drought stress in Eucalyptus spp. Forestry Studies / Metsanduslikud Uurimused 67 (1): 86-96. - doi: 10.1515/fsmu-2017-0014

Savolainen O, Lascoux M, Merilä J (2013). Ecological genomics of local adaptation. Nature Reviews Genetics 14: 807-820. - doi: 10.1038/n rg3522

Scheepens JF, Frei ES, Stöcklins J (2010). Genotypic and environmental variation in specific leaf area in a widespread Alpine plant after transplantation to different altitudes. Oecologia 164: 141-150. - doi: 10.1007/s00442-010-16500

Sefton CA, Montagu K, Atwell BJ, Conroy JP (2002). Anatomical variation in juvenile eucalypt leaves accounts for differences in specific leaf area and $\mathrm{CO}_{2}$ assimilation rates. Austrian Journal of Botany 50: 301-310. - doi: 10.1071/ BT01059

Steane DA, Mclean EH, Potts BM, Prober SM, Stock WD, Stylianou VM, Vaillancourt RE, Byrne M (2017). Evidence for adaptation and acclimation in a widespread eucalypt of semi-arid Australia. Biological Journal of the Linnean Society 121: 484-500. - doi: 10.1093/biolinnean/blw051

Thongo M'Bou A (2008). Etude du système racinaire de l'Eucalyptus en plantation tropicale: analyse architecturale, croissance et respiration. [Study of the root system of Eucalyptus in tropical plantations: architectural analysis, growth and respiration]. Thèse de l'Université Henri Poincaré, Nancy I et de l'Université Marien Ngouabi, Brazzaville, Republic of Congo, pp. 183. [in French] [online] URL: http://hal.univlorraine.fr/tel-01748463

Thumma BR, Sharma N, Southerton SG (2012). Transcriptome sequencing of Eucalyptus camaldulensis seedlings subjected to water stress reveals functional single nucleotide polymorphisms and genes under selection. BioMedCentral Genomics 13: 364. [online] URL: http:// www.biomedcentral.com/1471-2164/13/364 Vandewalle M, De Bello F, Berg MP, Bolger T, Dolédec S, Dubs F, Feld CK, Harrington R, Harrison PA, Lavorel S, Da Silva PM, Moretti M, Nie- 
mela J, Santos P, Sattler T, Sousa JP, Sykes MT, Vanbergen AJ, Woodcock BA (2010). Functional traits as indicators of biodiversity response to land use changes across ecosystems and organisms. Biodiversity Conservation 19: 29212947. - doi: 10.1007/s10531-010-9798-9

VanWallendael A, Soltani A, Emery NC, Peixoto MM, Olsen J, Lowry DB (2019). A molecular view of plant local adaptation: incorporating stress-response networks. Annual Review of Plant Biology 70: 559-83. - doi: 10.1146/annurevarplant-050718-100114

Vile D, Garnier E, Shipley B, Laurent G, Navas ML, Roumet C, Midgley GF (2005). Specific leaf area and dry matter content estimate thickness in laminar leaves. Annals of Botany 96 (6): 11291136. - doi: 10.1093/aob/mci264

Wright IJ, Reich PB, Westoboty M, Ackerly DD, Baruch Z, Bongers F, Cavender-Bares J, Chapin T, Cornelissen JHC, Diemer M, Flexas J, Garnier E, Groom PK, Gulias J, Hikosaka K, Lamont BB, Lee T, Lee W, Lusk C, Midgley JJ, Navas ML, Niinemets $\mathrm{U}$, Oleksyn J, Osada N, Poorter H, Poot P, Prior L, Pyankov VI, Roumet C, Thomas SC, Tjoelker MG, Veneklaas EJ, Villar R (2004). The worldwide leaf economics spectrum. Nature 428 (6985): 821-827. - doi: 10.1038/nature02403 Wright SJ, Zhou DC, Kuhle A, Olsen KM (2018). Continent-wide climatic variation drives local adaptation in North American white clover.
Journal of Heredity 109 (1): 78-89. - doi: 10.1093/ jhered/esxo6o

\section{Supplementary Material}

Tab. S1 - Climatic variables at the sites of seed origin and at the planting site.

Tab. S2 - Characteristics of the studied species indicating provenance and number of sampled trees at the beginning of the experiment.

Link: Makouanzi_366o@supploo1.pdf 